13 Huang J, van Gelder JM. The probability of sudden death from rupture of intracranial aneurysms: a meta-analysis. Neurosurgery 2002:51:1101-5.

14 Linn FH, Wijdicks EF, van der Graaf Y, Weerdesteyn-van Vliet FA, Bartelds AI, van Gijn J. Prospective study of sentinel headache in aneurysmal subarachnoid haemorrhage. Lancet 1994;344:590-3.

15 Polmear A. Sentinel headaches in aneurysmal subarachnoid haemorrhage: what is the true incidence? A systematic review. Cephalalgia 2003;23:935-41

16 Warlow CP, Dennis MS, van Gijn J, Hankey GJ, Sandercock PAG, Bamford JM, et al. What caused this subarachnoid haemorrhage? Stroke. A practical guide to management. Oxford: Blackwell Science, 2001:376-413.

17 Van der Wee N, Rinkel GJ, Hasan D, van Gijn J. Detection of 7 Van der Wee N, Rinkel GJ, Hasan D, van Gijn J. Detection of
subarachnoid haemorrhage on early CT: is lumbar puncture still needed after a negative scan? J Neurol Neurosurg Psychiatry 1995;58:357-9.

18 Van Gijn J, Rinkel GJE. How to do it: investigate the CSF in a patient with sudden headache and a normal CT brain scan. Pract Neurol 2005;5:362-5.

19 Van Gijn J, Rinkel GJ. Subarachnoid haemorrhage: diagnosis, causes and management. Brain 2001;124:249-78.

20 Williams A. Xanthochromia in the cerebrospinal fluid. Pract Neurol 2004;4:174-5

21 UK National External Quality Assessment Scheme for Immunochemistry Working Group. National guidelines for analysis of cerebrospinal fluid for bilirubin in suspected subarachnoid haemorrhage. Ann Clin Biochem 2003;40:481-8

22 Linn FH, Voorbij HA, Rinkel GJ, Algra A, van Gijn J. Visual inspection versus spectrophotometry in detecting bilirubin in cerebrospinal fluid. Neurol Neurosurg Psychiatry 2005;76:1452-4.

23 Vermeulen M, van Gijn J. The diagnosis of subarachnoid haemorrhage. J Neurol Neurosurg Psychiatry 1990;53:365-72.

24 White PM, Wardlaw JM, Easton V. Can non-invasive imaging accurately depict intracranial aneurysms? A systematic review. Radiology 2000;217:361-70

25 Van Gelder JM. Computed tomographic angiography for detecting cerebral aneurysms: implications of aneurysm size distribution for the sensitivity, specificity, and likelihood ratios. Neurosurgery 2003;53:597-605.

26 Hackett ML, Anderson CS, for the Australasian Cooperative Research on Subarachnoid Hemorrhage Study (ACROSS) Group. Health outcomes 1 year after subarachnoid hemorrhage: an international population-based study. The Australian Cooperative Research on Subarachnoid Hemorrhage Study Group. Neurology 2000;55:658-62.
27 Locksley HB. Natural history of subarachnoid hemorrhage, intracranial aneurysms and arteriovenous malformations. Based on 6368 cases in the cooperative study.J Neurosurg 1966;25:321-68.

28 Warlow CP, Dennis MS, van Gijn J, Hankey GJ, Sandercock PAG, Bamford JM, et al. Specific treatment of aneurysmal subarachnoid haemorrhage. Stroke. A practical guide to management. Oxford: Blackwell Science, 2001:518-59.

29 Vermeij FH, Hasan D, Bijvoet HW, Avezaat CJ. Impact of medical treatment on the outcome of patients after aneurysmal subarachnoid hemorrhage. Stroke 1998;29:924-30.

30 Amaragiri SV, Lees TA. Elastic compression stockings for prevention of deep vein thrombosis. Cochrane Database Syst Rev 2000;(3):CD001484.

31 Lacut K, Bressollette L, Le Gal G, Etienne E, De Tinteniac A, Renault A, et al. Prevention of venou hro hemorrhage. Neurology 2005:65:865-9.

32 Molyneux AJ, Kerr RS, Yu LM, Clarke M, Sneade M, Yarnold JA, et al. International subarachnoid aneurysm trial (ISAT) of neurosurgical clipping versus endovascular coiling in 2143 patients with ruptured intracranial aneurysms: a randomised comparison of effects on survival, dependency, seizures, rebleeding, subgroups, and aneurysm occlusion Lancet 2005;366:809-17.

33 Society of British Neurological Surgeons, the British Society of Neuroradiologists, and the Royal College of Surgeons of England, Clinical Effectiveness Unit National comparative outcomes study of subarachnoid haemorrhage. London: Royal College of Surgeons of England, Clinical Effectiveness Unit, 2006.

34 Baltsavias GS, Byrne JV, Halsey J, Coley SC, Sohn MJ, Molyneux AJ Effects of timing of coil embolization after aneurysmal subarachnoid hemorrhage on procedural morbidity and outcomes. Neurosurger 2000;47:1320-9.

35 Heiskanen O, Poranen A, Kuurne T, Valtonen S, Kaste M. Acute surgery for intracerebral haematomas caused by rupture of an intracranial arterial aneurysm. A prospective randomized study. Acta Neurochir (Wien) 1988;90:81-3.

36 Feigin VL, Rinkel GJ, Lawes CM, Algra A, Bennett DA, van Gijn J, et al. Risk factors for subarachnoid hemorrhage: an updated systematic review of epidemiological studies. Stroke 2005;36:2773-80.

37 Teasdale GM, Wardlaw JM, White PM, Murray G, Teasdale EM, Easton V, et al. The familial risk of subarachnoid haemorrhage. Brain 2005; 128:1677-85.

(Accepted 19June 2006)

\title{
Who decides?
}

Tom had been an active child, enjoving school and playing football. More importantly, he was a central part of his family. He was born with an atrioventricular septal defect and trisomy 21. At that time, intervention had been thought to be too risky and, as a result, he had frequent hospital admissions and poor exercise tolerance. Outcomes and perceptions changed, and, at 7 years old, he underwent surgical repair (pulmonary vascular resistance was low). This led to four fun years of walking and playing.

We met him when he was 13 years old, and he was six months into his ordeal. He had had recurrent arterial thromboemboli, resulting in occlusion of the aorta at the bifurcation. After an embolectomy and a long stay in the paediatric intensive care unit, his medical problems included renal failure, lower limb paralysis, and severe back pain. As plans for discharge were made, with home care and equipment being organised, he became unwell again. Because of his recent traumatic experiences, Tom and his family were not keen on transfer back to intensive care. Optimal medical therapy was continued.

Tom quickly became withdrawn. He was quiet and scared. He barely ate or drank. Venepuncture had made him angry, but this changed: at first he would cry, and then he just lay still and silent. His sleep was broken. Up to this point, his mother, brothers, and certain nurses could easily bring on laughter even when he was in pain or frustrated.

Although there were no direct discussions with him, we took his cue. Like other teenagers, he had been exposed to death, and some of his school friends had died. His understanding was limited but not poor. For example, he said that being in intensive care was being dead and that going back was dying again. From a medical standpoint, the prognosis for his condition was undefined and the chances of him surviving the current acute problem were low. His family faced these issues with us bravely.

When all his family and friends began arriving and the needles stopped, he was different. The laughter returned, as did his appetite for McDonalds. His spirit returned, and his dislike for wheelchairs did not stop him going to meet Michael Owen (he did the 30 mile round trip on a stretcher). His last few days were happy, and he was surrounded by those he loved.

We remain inspired by Tom and his family.

Jasveer Singh Mangat specialist registrar in paediatric cardiology (jasveer mangat@yahoo.com),Priya Kumar specialist registrar in paediatrics, Guy's and St Thomas' NHS Trust, Londom

We welcome articles up to 600 words on topics such as A memorable patient, A paper that changed my practice, $M y$ most unfortunate mistake, or any other piece conveying instruction, pathos, or humour. Please submit the article on http://submit.bmj.com Permission is needed from the patient or a relative if an identifiable patient is referred to. We also welcome contributions for "Endpieces," consisting of quotations of up to 80 words (but most are considerably shorter) from any source, ancient or modern, which have appealed to the reader. 